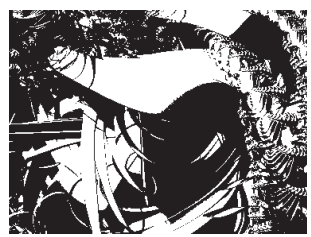

\title{
IZMEĐU VRIJEDNOSTI OBRAZOVANJA I NEGATIVNOGA SOCIOKULTURNOG NASLJEĐA
}

Antun ŠUNDALIĆ, Želiko PAVIĆ Ekonomski fakultet, Osijek

UDK: $316.66(497.5): 316.752$ $316.752(497.5): 343.352$

Izvorni znanstveni rad

Primljeno: 8. 6. 2011.

Unatoč složenosti pojma meritokracije, u meritokratskim bi društvima društveni položaj i društvene nagrade trebali biti usko povezani sa stupnjem obrazovanja pojedinaca. $U$ hrvatskom je društvu nemeritokratsko, koruptivno ponašanje vrlo izraženo, a objašnjenja njegovih uzroka kreću se od upozoravanja na nepovoljno sociokulturno nasljeđe (tradicionalna seljačka kultura, socijalizam) do racionalne adaptacije na društvenu stvarnost. U ovome se radu, na osnovi istraživanja prihvaćenosti vrijednosti obrazovanja kao mehanizma društvene selekcije i nagrađivanja te prihvaćanja koruptivnih načina dolaženja do društvenog uspieha, pokušava utvrditi u kojoj se mjeri još uvijek može govoriti o negativnom utjecaju sociokulturnoga nasljeđa. Istraživanje rađeno na prigodnom uzorku studenata Sveučilišta J. J. Strossmayera u Osiieku na početku 2011. godine pokazalo je da ispitanici smatraju kako se procesi zauzimanja društvenih položaja odvijaju nemeritokratski. Međutim, kod samih ispitanika istodobno prevladava meritokratski svjetonazor, dok se manji dio nijh adaptirao na društvenu stvarnost prihvaćajući u isti mah vrijednost obrazovanja, ali iskazujući i prihvaćanje koruptivnoga ponašanja. Imajući na umu da se kod većine onih koji su spremni na koruptivno ponašanje pojavljuje vrijednosna disonanca, autori zaključuju da u pozadini ove spremnosti vierojatno stoji racionalna adaptacija na stvarnost.

Ključne riječi: obrazovanje, meritokracija, vrijednosna disonanca, društvene vrijednosti, korupcija 
Kapitalistička je ekonomija primarno određena tržištem. Tržište nije samo odnos na razini gospodarskih subjekata i roba, ono je i kriterij individualnog uspjeha. Načelno, neoliberalna ideologija zagovara pravo svakoga pojedinca da ostvari svoje sposobnosti, da razvije svoj talent (Friedman, 1992.). Pritom svaki pojedinac preuzima i rizik konačnog ishoda: uspješna ili neuspješna karijera, uspon na socijalnoj ljestvici uspjeha ili pad. Na društvu je jedina odgovornost da omogući ujednačene uvjete razvoja svakoga pojedinca, a društveni je položaj pojedinaca rezultat njihova truda i sposobnosti. Ovakva, naizgled samorazumljiva, ideja meritokracije $u$ daljnjoj se razradbi pokazuje nešto složenijom i višeznačnijom. Općenito govoreći, društvena nejednakost, odnosno zauzimanje društvenih položaja koje karakteriziraju različite količine društveno poželjnih resursa (novca, statusa, moći ...), može se protumačiti i pokušati opravdati na četiri temeljna načina (modificirano na temelju Goldthorpe, 1997.):

1. razlike na temelju obrazovanja (formalnih kvalifikacija)

2. razlike na temelju tržišnih rezultata postignutih na legalan način

3. razlike do kojih je došlo na temelju nelegalnih postupaka

4. razlike na temelju obiteljskoga podrijetla.

Prema prvom shvaćanju, društvene nejednakosti proizlaze iz različitih obrazovnih kvalifikacija, koje bi opet u konačnici trebale odražavati različite razine sposobnosti i uloženoga truda. Prema drugom shvaćanju, tržišno stvorena vrijednost osnovni je čimbenik stvaranja društvenih nejednakosti. Svi oni tržišni rezultati do kojih se došlo poštujući temeljna pravila tržišne utakmice opravdani su. Ovakvo shvaćanje u izvjesnoj je napetosti s kredencijalističkim shvaćanjem, koje formalne kvalifikacije smatra jedinim legitimnim korijenom društvenih nejednakosti. Očito je, naime, da tržišno postignuti ishodi nisu posve sukladni s formalnim obrazovnim kvalifikacijama koje posjeduju tržišni akteri, jer ti ishodi ovise i o sreći, socijalnim vezama i svim drugim sposobnostima koje ne moraju biti izrazito povezane s formalnim kvalifikacijama pojedinca. Prema trećem shvaćanju, društvene razlike nastaju na temelju postupaka koji su društveno definirani kao nelegalni (mito, nepotizam, političke veze, prijateljske veze i usluge i sl.). Ovakvi postupci, iako nelegalni, u pojedinim društvima mogu biti široko prakticirani i prešutno prihvaćeni. Razlike na temelju obiteljskoga podrijetla (četvrto shvaćanje) rezultat su svih onih resursa koje pojedinac ima zahvaljujući njihovu intergeneracijskom prenošenju. Ovi resursi mogu obuhvaćati imovinu, obiteljske društvene veze, mogućnost stjecanja kvalitetnog obrazovanja, kulturni kapital (stil, način izražavanja ...), 
DRUŠ. ISTRAŽ. ZAGREB GOD. 20 (2011),

BR. $4(114)$

STR. $943-965$

ŠUNDALIĆ, A., PAVIĆ, Ž.: IZMEĐU VRIJEDDNOSTI... poduzetničko znanje ili iskustvo i slično. Nije posve jasno je li prenošenje ovih resursa legitimno ili nelegitimno, tj. prihvaćaju li ih ljudi kao moralno opravdane ili neopravdane, smatraju li ih meritokratskim ili nemeritokratskim. S jedne je strane prihvatljivo da pojedinci ono što su stekli tijekom života (materijalni, socijalni ili kulturni kapital) prenesu na svoju djecu; štoviše, to se na neki način i smatra dijelom njihove roditeljske odgovornosti. S druge strane, postoji društvena nesklonost $\mathrm{u}$ odnosu na sve one resurse koji su naslijeđeni i koji nekim pojedincima daju subjektivno nezaslužene bolje početne pozicije u životu. Je li, primjerice, meritokratski da neki pojedinci zbog svojega socijalnog podrijetla mogu brzo steći veliku imovinu (tj. naslijediti je), dobiti kvalitetno obrazovanje, poznavati društveno utjecajne ljude i slično?

No unatoč ovim konceptualnim nedoumicama i složenosti pojma meritokracije, društveni uspjeh stečen nelegalnim načinima sasvim se sigurno ne može smatrati meritokratskim. Isto tako, unatoč nepredvidljivosti tržišnog uspjeha i poteškoćama njegova povezivanja s idejom "zasluge", koja je u temelju ideje meritokracije, obrazovanje se može smatrati djelomičnim, a empirijski gledano i najlakše utvrdivim indikatorom meritokracije. Meritokracija u sebi sadrži vrijednost obrazovanja kao regulativnu ideju, u meritokratskom društvu društveni položaj pojedinca trebao bi biti uže vezan s količinom obrazovanja koju taj pojedinac ima.

U hrvatskom je društvu obrazovanje na političko-deklarativnoj razini prihvaćeno ne samo kao osnovni pokretač gospodarskoga rasta i tehnološkoga napretka nego i kao mehanizam pravednoga (meritokratskog) dodjeljivanja društvenih položaja i nagrada. Osnovna tema ovoga rada nalazi se u analiziranju mogućnosti postojanja vrijednosne disonance, koja se očituje u nepodudaranju između (ne)prihvaćanja vrijednosti obrazovanja kao meritokratskoga mehanizma i (ne)prihvaćanja koruptivnih načina dolaženja do društvenog uspjeha. Naime, objašnjenja izrazite rasprostranjenosti različitih oblika koruptivnoga ponašanja u hrvatskom društvu mogu se kretati u nekoliko pravaca. $S$ jedne strane možemo pretpostaviti da postoji sociokulturno nasljeđe nepotizma i korupcije, koje nisko vrednuje meritokratske implikacije obrazovanja, a visoko koruptivne načine dolaženja do društvenih pozicija. S druge strane, prihvaćanje koruptivnih putova uspjeha može biti odraz adaptacije na stvarnost, a ne izraz niskoga vrednovanja obrazovanja kao mehanizma društvene selekcije i nagrađivanja. Drugačije govoreći, u potonjem slučaju na djelu može biti mehanizam socijalnog učenja, u kojem percepcija raširenosti koruptivnih ponašanja pridonosi njihovu daljnjem održavanju, tj. spremnosti na takvo postupanje kod pojedinaca (Akers, 2009.; Tavits, 2010., 1260). 
DRUŠ. ISTRAŽ. ZAGREB GOD. 20 (2011),

BR. $4(114)$

STR. 943-965

ŠUNDALIĆ, A., PAVIĆ, Ž.: IZMEĐU VRIJEDENOSTI...
U istraživačkom dijelu rada (na studentskom uzorku) pokušat će se, kroz operacionalizaciju tipologije suodnošenja spomenutih dviju vrijednosti, utvrditi u kojoj se mjeri obrazovanje prihvaća kao meritokratski mehanizam, tj. možemo li u tom smislu još uvijek govoriti o pretpostavljenom negativnom utjecaju sociokulturnoga nasljeđa. Nadalje, pokušat će se utvrditi u kojoj je mjeri prisutna adaptacija na društvenu realnost, tj. koliko se često visoko vrednovanje meritokratske uloge obrazovanja povezuje s prihvaćanjem nemeritokratskih (koruptivnih) načina društvenog uspjeha. S obzirom na to da je istraživanje rađeno na studentskoj populaciji, koja ipak ima donekle ograničeno iskustvo sudjelovanja u mehanizmu društvene selekcije i nagrađivanja, prisutnost meritokratskih ili nemeritokratskih vrijednosti kod ove populacije može upućivati na (ne)postojanje sociokulturnoga nasljeđa, koje primarnom socijalizacijom utječe na disponiranost za koruptivno ponašanje. Na ovaj se način pokušava djelomično odgovoriti na dilemu o kulturološkoj i/ili racionalnoj toleranciji korupcije u hrvatskom društvu (Čaldarović i sur., 2009., 8-9).

\section{SOCIOKULTURNO NASLJEĐE I MERITOKRACIJA U HRVATSKOJ}

Nekadašnji društveni procesi i okolnosti u kojima se razvijalo hrvatsko društvo nisu bili skloni razvoju meritokratskih obrazaca društvene selekcije, a može se pretpostaviti da neki od tih procesa djeluju i danas. Društveni razvoj Hrvatske u 20. stoljeću obilježilo je prepletanje negativnoga nasljeđa tradicionalnoga seljačkog društva i nedemokratskih političkih režima, a ni tranzicijsko vrijeme i ratne okolnosti nisu pružili pogodan okvir za razvoj meritokratskih oblika razmišljanja i djelovanja.

Za bolje razumijevanje ovih društvenih procesa korisno se vratiti u prošlo stoljeće. Korupcija je posebice obilježila razdoblje prve Jugoslavije. To je vrijeme između dva svjetska rata, u kojemu su, ističe R. Bićanić, korupcija, mito i nepotizam pokrivali sve djelatnosti, posebice državne službe. "Od prostog primanja mita, ucjenjivanja, prodavanja povjerenih interesa za gotov novac, pak do najraznoličnijih 'veza', protekcija, nepotizama, za gotovo ili za 'trampu', za isto takve protuusluge na štetu države ili trećih, do zadobijanja poslanika sa strane mjerodavnih, udovoljavanjem plaćenih ili inače rekompenziranih poslaničkih intervencija, do trošenja ogromnih državnih sredstava u javne radove - zapravo izborne fondove - pojedinih ličnosti, klika i partija itd." (Bićanić, 2004., 113). ${ }^{1}$ U drugoj je Jugoslaviji centralizacija u okviru socijalizma i dalje davala prostora nemogućnosti kontrole birokratskog aparata, a time i stvarala strukturu koruptivnih mogućnosti koja je postojala u tom razdoblju. Naime, osim postojanja tradicije nepotizma naslijeđene iz tradicionalnoga seljačkog dru- 
DRUŠ. ISTRAŽ. ZAGREB GOD. 20 (2011),

BR. $4(114)$

STR. $943-965$

ŠUNDALIĆ, A., PAVIĆ, Ž.: IZMEĐU VRIJEDDNOSTI... štva, kao što je bio slučaj u socijalističkoj Hrvatskoj, socijalističko je razdoblje svim državama u nasljeđe ostavilo koruptivne norme ponašanja, koje su kulturnom inercijom vjerojatno nastavile postojati sve do danas. Kako pokazuju Sandholtz i Taagepera (2005.), komandne su ekonomije i jednopartijski sustavi nudili strukturne mogućnosti razvoja korupcije. Monopolistički položaj tvrtki nudio je mogućnost financiranja korupcije iz visokih renti, a neodgovorna državna administracija, nepodložna demokratskoj kontroli, također je pogodovala korupciji. Nove su se strukturalne mogućnosti otvorile privatizacijom u postsocijalističkom razdoblju, kada je masovna preraspodjela resursa išla ruku pod ruku s urušavanjem prijašnjih kontrolnih mehanizama, koji su korupciju držali pod djelomičnom kontrolom. Zbog toga nije ni čudno da isti autori (Sandholtz i Taagepera, 2005.), empirijskom analizom rezultata World Values Survey, pokazuju da nekadašnje socijalističke zemlje pokazuju sustavno više razine korupcije, čak i kada se kontrolira učinak dviju vrijednosnih osi (tradicionalizam - sekularizam, samoekspresija - vrijednost preživljavanja).

Osim pružanja mogućnosti razvoja koruptivnih oblika ponašanja, socijalističko je razdoblje, ponajviše zbog egalitarnih tendencija i političke autokracije, donijelo i spornu ulogu obrazovanja kao mehanizma društvenog uspjeha i nagrađivanja. Naime, socijalistička se ideologija suprotstavljala onoj liberalnoj koncepcijom socijalne sigurnosti i egalitarizma. Ono što je sa sobom donijelo tržište - sve nejednakosti i nesigurnost ishoda u tržišnoj borbi meritokracije - socijalizam je uklonio dogovornom ekonomijom, koja nije pojedinca osamljivala ni kada je riječ o uspjehu ni kada mu se dogodi neuspjeh. Josip Županov je, pokušavajući analizirati tržišno-samoupravne reforme u socijalizmu, upozorio na to da većina radništva nije spremna preuzeti poduzetničke uloge u poduzećima jer dolazi iz okvira seljačkoga društva u kojima je dominirala naturalna ekonomija i u kojoj su poduzetništvo i tržište predstavljali neprijateljsku i razornu silu (Županov, 1985., 28). ${ }^{2}$ Tako se $\mathrm{u}$ istraživanjima provedenima tijekom tzv. privredne reforme polovicom šezdesetih godina 20 . stoljeća pokazalo da većina zaposlenika u poduzećima ne prihvaća tržišna pravila igre te da su neskloni prihvaćanju poduzetničkoga rizika, iako treba naglasiti da je prihvaćanje tržišta i rizika bilo veće kod "rukovodilaca" (današnjim jezikom: menadžera) nego kod nekvalificiranih i kvalificiranih radnika (Županov, 1985., 32-55).

S druge strane, ulogu obrazovanja u spletu drugih čimbenika socijalne pokretljivosti pokazuju empirijska istraživanja rađena na području socijalističke Hrvatske (Lazić, 1987.; Sekulić, 1991.). ${ }^{3}$ Ova istraživanja pokazuju relativnu otvorenost društvene strukture, koja je i razumljiva ako se imaju na umu strukturne promjene vezane uz nastanak (post)indus- 
DRUŠ. ISTRAŽ. ZAGREB GOD. 20 (2011)

BR. 4 (114),

STR. 943-965

ŠUNDALIĆ, A., PAVIĆ, Ž.: IZMEĐU VRIJÉDNOSTI... trijskoga društva (širenje sloja profesionalaca), političke promjene, kao i činjenicu da je agrarno društvo pružalo izdašan izvor značajne međugeneracijske pokretljivosti. ${ }^{4} \mathrm{Za}$ ovaj su rad, međutim, važniji podaci o značajnoj unutargeneracijskoj pokretljivosti i njezinoj vezanosti uz obrazovne kvalifikacije. Naime, u prvom istraživanju oko $42 \%$ političkih rukovoditelja i direktora te oko $25 \%$ profesionalaca ("posredna klasa") svoj su radni vijek započeli u radničkom sloju, iako u većem broju slučajeva kao službenici i tehničari, a u znatno manjem broju kao manualni radnici (Lazić, 1987., 107-108). S obzirom na to da su profesionalci po definiciji visokoobrazovani te da su gotovo svi direktori i oko $85 \%$ političkih rukovoditelja imali više ili visoko obrazovanje, očito je da su obrazovne kvalifikacije bile važan mehanizam uzlazne unutargeneracijske pokretljivosti. Slične se brojke mogu naći i kod Sekulića; npr. 44\% direktora $\mathrm{u}$ tom istraživanju profesionalnu karijeru započelo je kao službenici ili radnici (Sekulić, 1991., 180). Ovakvu meritokratsku sliku "kvari" podatak o vrlo važnom utjecaju članstva u Savezu komunista na uspon na društvenoj ljestvici. Naime, članovi su bili 2,5 do 4 puta češće uzlazno pokretljiviji od nečlanova, a prednost članstva vrijedi za uzlaznu pokretljivost iz svih slojeva (Lazić, 1987., 153-154). I prema Sekulićevoj analizi članovi SK-a u svim socijalnim slojevima bili su znatno uzlazno mobilniji od nečlanova. Dakle, nije bilo riječi samo o zauzimanju elitnih pozicija nego su članovi SK-a tijekom života češće prelazili iz manualnih u nemanualna zanimanja (Sekulić, 1991., 237-249). Ovakvi podaci upućuju na zaključak da su obrazovne kvalifikacije bile nuždan, ali vjerojatno često i nedovoljan, mehanizam društvenoga napredovanja, premda nije jednostavno reći u kojoj se mjeri radilo o instrumentalnoj funkciji partijskoga članstva, a u kojoj o činjenici da su uzlazno mobilniji možda bili zainteresiraniji za političko aktiviranje.

Egalitarni vrijednosni obrasci naslijeđeni iz tradicionalne kulture, koji su nastavili živjeti u socijalizmu u modificiranu obliku, našli su svoje uporište i u razdoblju tranzicije i hrvatske državne samostalnosti. S jedne je strane ratna oskudica i drastičan pad životnoga standarda gotovo prirodno implicirao egalitarizam i oslanjanje na državni paternalizam i redistribuciju. Zbog egzistencijalne ugroženosti, većina je građana državi pripisivala odlučujuću ulogu, ali i dužnost, u osiguravanju osobnoga i društvenoga blagostanja. Osim toga, ideologija nacionalne samostalnosti i zajedništva povlačila je za sobom i ideju da se država, kao utjelovljenje te zajednice, treba brinuti o svima i svima osigurati pristojan životni standard. Sažeto govoreći, početne godine hrvatske samostalnosti zacijelo nisu bile poticajan kontekst za nastanak liberalno-tržišnoga vrijednosnog sustava, u kojemu bi tržišno stvorena 
DRUŠ. ISTRAŽ. ZAGREB GOD. 20 (2011), BR. $4(114)$

STR. $943-965$

ŠUNDALIĆ, A., PAVIĆ, Ž.: IZMEĐU VRIJEDDNOSTI... vrijednost vezana uz stručnost pojedinca, a ne "potrebe" ili "zasluge", bila odlučujući čimbenik nagrađivanja (Sundalić, 2004. 94-96). Istodobno se redistribucija ekonomske i političke moći u Hrvatskoj dogodila nemeritokratski. Pojedinci i skupine koji su preuzeli odgovornost razvijanja kapitalizma u Hrvatskoj nisu to zaslužili u tržišnoj utakmici ni kvalitetnim obrazovanjem u poduzetništvu i menadžmentu. Čak ih većina nije ni naslijedila "obiteljsko znanje i tradiciju" gospodarenja imovinom i organiziranja proizvodnje. Nastala gospodarska elita u većini slučajeva nije selekcionirana kompetitivno, već kriterijem političke podobnosti i nepotizma. Takvoj poduzetničkoj eliti, kojoj je primarni cilj posjedovanje i trošenje, Županov dodjeljuje atribute dezindustrijalizirajuće, descijentizirajuće, retradicionalizirajuće i birokratske elite (Županov, 2001., 22-33). Tranzicijsko je razdoblje hrvatskoga društva bilo obilježeno vertikalnom socijalnom mobilnošću, koja se ne može smatrati pravednom i zasluženom (uspinjanje na ljestvici socijalnog uspjeha mimo kriterija uspjeha u obrazovanju, profesiji, tržišnom natjecanju i sl.). Ovaj drugi proces možemo prepoznati upravo u novonastajućoj političkoj i gospodarskoj eliti. Iako se može govoriti o naznakama profesionalizacije menadžera potkraj socijalističkoga razdoblja (Pusić, 1992.), na temelju usporedbe anketnih istraživanja rađenih 1989. i 1996. godine B. Krištofić zaključuje da je došlo do pada stupnja obrazovanja hrvatskih direktora. Tako je 1989. njih 97\% imalo više ili visoko obrazovanje, dok je taj udio 1996. pao otprilike na 74\% (Krištofić, 1997., 48). Iako je pojava novoga sloja vlasnika-menadžera sigurno dijelom objašnjavala ovaj pad, pokazuje se da su pad socijalizma "preživjeli" upravo oni direktori koji su bili stariji i manje obrazovani, ali očito i snalažljiviji. Učlanjenje u novu vladajuću stranku i/ili prihvaćanje nove nacionalne ideologije omogućilo im je očuvanje vlastite pozicije, a u mnogim slučajevima i preuzimanje vlasničkog udjela u tvrtkama u kojima su bili zaposleni (Krištofić, 1997., 48-65). Društvena transformacija obilježena političkim pravilima igre i od javnosti ocijenjena je izrazito nepravednom. Tako se dobitnicima privatizacije smatraju članovi vladajuće stranke, političari i menadžeri, a gubitnicima seljaci, radnici i stručnjaci (Štulhofer, 1999.).

Hrvatsko je društvo na svojem tranzicijskom putu nužno prihvatilo razvojnu i progresivnu ulogu i značenje obrazovanja. Čak se u političkim koncepcijama društvenoga razvoja često spominjala sintagma "društvo znanja", kojom se željelo ustvrditi da je jedina orijentacija budućnosti hrvatskoga društva obrazovanje i znanost. Ova načelna orijentacija, međutim, nije još uvijek i realnost društvenih promjena. Obrazovanje još uvijek nije u sustavu društvenih vrijednosti najvažniji put do uspjeha u karijeri, a time i do ugleda u društvu. Neke su druge vrijednosti vjerojatno još ponekad poželjne 
kao lakši, brži i sigurniji put do uspjeha. Meritokratska je koncepcija u našoj sredini često zamijenjena naslijeđenim (i dalje održavanim!) obrascima korupcije, nepotizma, podobnosti i "amoralnoga familizma". 5

\section{TEORIJSKO-HIPOTETSKI OKVIR ISTRAŽIVANJA}

Na temelju razmatranja spomenutih društvenih procesa i specifičnih razvojnih okolnosti hrvatskoga društva, u istraživačkom dijelu ovoga rada postavljene su sljedeće hipoteze:

H1: Unatoč nepovoljnom sociokulturnom nasljeđu, obrazovanje će biti visoko vrednovano kao mehanizam meritokratske selekcije i nagrađivanja.

Kao što poduzetnički kapitalizam postupno jača i potiskuje državni kapitalizam, a tržišna samokontrola državnu kontrolu, ${ }^{6}$ tako se i novi naraštaji sve više okreću stvarnosti globalnog okruženja, a ne navikama starijih generacija. Obrazovanje je danas globalna poluga promjene, bilo da je riječ o socijalnoj mobilnosti vezanoj za profesionalni uspjeh i društveni ugled, bilo da je riječ o političkoj demokratizaciji u nerazvijenim zemljama. Internetizacija svijeta učinila je znanje dostupnijim i ubrzala protok informacija. Sve je teže vjerovati da konkurencija, utemeljena na stručnosti, neće biti stvarnost i ovoga dijela svijeta. Mladi koji se školuju znaju za ovakvu stvarnost okruženja te ponajviše u obrazovanju pronalaze sredstvo borbe za vlastiti socijalni položaj i uspjeh u karijeri.

H2: U hrvatskom društvu još uvijek prevladava mišljenje da za dolaženje na određene socijalne položaje (funkcije na čelu poduzeća, općine, grada, a posebice funkcije obnašanja političke vlasti) obrazovanje nije ključno.

Kako je ranije objašnjeno, socijalistički je egalitarizam u Hrvatskoj osporavao stručnost kao mehanizam društvenoga nagrađivanja, a društveni je položaj pojedinca bio pod jakim utjecajem partijskoga članstva. S druge strane, u kapitalizmu sposobniji i učinkovitiji u pravilu bolje preživljavaju tržišnu utakmicu od onih koji to nisu. Sve prisutnija znanost kao moćan društveni pokretač, tzv. tehnoznanost (Morin, 2008., 70), $\mathrm{u}$ tehnologiji proizvodnih procesa otvara velik prostor obrazovanoj populaciji, koja postaje lokomotiva gospodarskoga rasta i društvenoga razvoja. Na razini proklamiranih društvenih vrijednosti, karijera se u kapitalističkom društvu primarno temelji na ostvarenom stupnju obrazovanja, iako empirijska istraživanja rađena u razvijenim zapadnim zemljama u zadnjih nekoliko desetljeća ne pružaju jasne dokaze u pri- 
DRUŠ. ISTRAŽ. ZAGREB GOD. 20 (2011), BR. $4(114)$

STR. $943-965$

ŠUNDALIĆ, A., PAVIĆ, Ž.: IZMEĐU VRIJEDNOSTI.

(1) TABLICA 1

Tipologija suodnošenja vrednovanja obrazovanja i vrednovanja koruptivnih načina društvenog uspieha log sve većem značenju obrazovanja za postizanje socijalnoga položaja (za pregled istraživanja vidjeti Goldthope, 1997.). U svakom slučaju, ovom se hipotezom predviđa da će stavovi studenata odražavati hrvatsku društvenu stvarnost u kojoj su socijalno podrijetlo, stranačka pripadnost, rodbinske i zavičajne veze važnije od obrazovanja kada je u pitanju zauzimanje važnijih društvenih položaja.

H3: Vrijednosna disonanca bit će vrlo izražena kod onih pojedinaca koji prihvaćaju koruptivne načine dolaženja do društvenog uspjeha.

Društvena stvarnost pokazuje da obrazovanje i formalne kvalifikacije nisu najvažniji put do društvenog uspjeha, a prema drugoj hipotezi ova stvarnost odražava se i u mišljenju ispitanika. Polazeći od toga da vrednovanje koruptivnih oblika postizanja društvenog uspjeha može biti sukladno ili nesukladno s vrednovanjem obrazovanja kao meritokratskoga mehanizma, ovaj se odnos može tipologizirati na način prikazan u Tablici 1.

\begin{tabular}{|c|c|c|}
\hline & Visoko vrednovanje obrazovanja & Nisko vrednovanje obrazovanja \\
\hline Prihvaćanje korupcije & $\begin{array}{l}\text { Disonanca (adaptacija na } \\
\text { društvenu stvarnost) }\end{array}$ & $\begin{array}{l}\text { Sociokulturno nasljeđe antiintelek- } \\
\text { tualizma, nepotizma i korupcije }\end{array}$ \\
\hline Odbijanje korupcije & $\begin{array}{l}\text { Meritokratska uvjerenja } \\
\text { i postupanje }\end{array}$ & Disonanca (antiintelektualizam) \\
\hline
\end{tabular}

Visoko prihvaćanje vrijednosti obrazovanja, uz istodobno prihvaćanje koruptivnih načina uspjeha, može se shvatiti kao adaptacija na društvenu stvarnost obilježenu nepotizmom, mitom, političkom podobnošću i drugim oblicima koruptivnoga ponašanja. Pojedinci se na taj način mogu prilagoditi stvarnosti nastaloj nakon anomijskoga sloma društvenoga poretka utjelovljenom u "predatorskom kapitalizmu" (Kregar, 1999.), koji nije mario ni za osnovne pravne norme, a kamoli visoko vrednovao obrazovanje. Ovakav tip odnošenja predstavlja vrijednosnu disonancu, koja se očituje u deklarativno visokom vrednovanju obrazovanja, ali i prihvaćanju koruptivnih načina društvenog uspjeha. Drugačije rečeno, pojedinci prihvaćaju meritokratsko značenje obrazovanja, no svjesni su da su načini dolaska do društvenog uspjeha drugačiji i da se nalaze negdje drugdje, pa ih kao takve i prihvaćaju. Kao što disonanca između proklamiranih društvenih normi i naslijeđenih društvenih vrijednosti može usporavati ili posve blokirati društveni razvoj (Lazić i Cvejić, 2007., 55-57), tako i vrijednosna disonanca može proklamirane društvene vrijednosti učiniti nefunkcionalnima. $U$ ovome bi slučaju pozitivno vredno- 
DRUŠ. ISTRAŽ. ZAGREB GOD. 20 (2011),

BR. $4(114)$

STR. 943-965

ŠUNDALIĆ, A., PAVIĆ, Ž.: IZMEĐU VRIJÉDNOSTI... vanje obrazovanja bilo "blokirano" pozitivnim vrednovanjem koruptivnoga ponašanja, pa bi i transformacija pozitivnoga vrednovanja obrazovanja u svakodnevno ponašanje bila znatno niža u usporedbi sa situacijom nepostojanja disonance. $S$ druge strane, istodobno prihvaćanje koruptivnih oblika ponašanja i nisko vrednovanje obrazovanja vjerojatno je nastavak sociokulturnih obrazaca naslijeđenih iz tradicionalnoga seljačkog društva, koji su nastavili živjeti i u socijalističkom i u postsocijalističkom razdoblju. Ako je ovakva vrsta odnosa česta, tada se može reći da su tradicionalni koruptivni sociokulturni obrasci koji se podcjenjivački odnose prema obrazovanju još uvijek aktualni $u$ hrvatskom društvu, tj. da postoji jak utjecaj sociokulturnoga nasljeđa. Treći tip odnosa između društvenih normi i vrijednosti obrazovanja pretpostavlja istodobno odbacivanje nelegalnih načina društvenog uspjeha i prihvaćanje vrijednosti obrazovanja, tj. meritokratski svjetonazor. Ovdje pojedinci ne samo da prihvaćaju vrijednost obrazovanja nego i odbijaju koruptivne načine postizanja društvenog uspjeha, iako su uglavnom svjesni njihova postojanja. Četvrti tip odnosa označuje situaciju u kojoj postoji odbacivanje korupcije, ali i odbacivanje vrijednosti obrazovanja. Može se pretpostaviti da ovakvo odnošenje predstavlja naslijeđeni sociokulturni antiintelektualizam ili nisko vrednovanje trenutačne kvalitete hrvatskoga obrazovnog sustava.

\section{OSNOVNI PODACI O ISTRAŽIVANJU I STRUKTURA UZORKA}

Podaci su prikupljeni metodom skupnog anketiranja studenata viših godina (studenata diplomskih studija) Sveučilišta J. J. Strossmayera u Osijeku u siječnju 2011. godine. Upitnik je sadržavao ukupno 24 pitanja različitih formata, a za potrebe ovoga rada iskorišten je dio dobivenih podataka. S obzirom na to da su u istraživanju sudjelovali oni studenti koji su prilikom anketiranja bili na nastavi, uzorak u ovome istraživanju bio je prigodan. Planirano je da u istraživanju sudjeluju studenti s područja društvenih, prirodnih, tehničkih i biomedicinskih znanosti, s tim da su neka znanstvena područja bila namjerno nadzastupljena $\mathrm{u}$ odnosu na njihov udio $\mathrm{u} u$ kupnom broju studenata zbog mogućnosti usporedbe s drugim područjima (veće pouzdanosti procjene). No s obzirom na to da je broj anketiranih studenata ovisio o broju prisutnih na nastavi, ostvareni plan uzorka razlikovao se od planiranoga (Tablica 2). S obzirom na to da se, iz istih razloga, pojavila i podzastupljenost muških ispitanika, obavljeno je ponderiranje podataka prema varijablama znanstvenoga područja i spola. Kao referentne vrijednosti uzeti su udjeli studenata po spolu i znanstvenim područjima koji su upisani na diplomske studije u školskoj godini 2010./11.7 
(1) TABLICA 2

Struktura uzorka

po znanstvenim

područjima i spolu

U istraživanju je sudjelovao 361 student, 131 muških $(36,3 \%)$ i 230 ženskih $(63,7 \%)$. Kada je u pitanju naselje u kojemu žive kada ne studiraju, 48,3\% ispitanih studenata živi na selu, a $51,7 \%$ u gradu. Struktura uzorka po znanstvenim područjima i spolu prikazana je u Tablici 2.

\begin{tabular}{|c|c|c|c|c|c|}
\hline Područje/znanosti & Sastavnica/fakultet & Spol & $\begin{array}{r}\text { Veličina prema } \\
\text { udjelu u ukupnom } \\
\text { broju studenata }\end{array}$ & $\begin{array}{r}\text { Planirana } \\
\text { veličina }\end{array}$ & $\begin{array}{r}\text { Ostvarena } \\
\text { veličina }\end{array}$ \\
\hline društvene & Ekonomski i Pravni & $\begin{array}{l}\mathrm{M} \\
\check{Z}\end{array}$ & $\begin{array}{r}87 \\
144\end{array}$ & $\begin{array}{r}83 \\
137\end{array}$ & $\begin{array}{r}72 \\
158\end{array}$ \\
\hline prirodne & Odjel za matematiku & $\begin{array}{l}\mathrm{M} \\
\check{Z}\end{array}$ & $\begin{array}{l}7 \\
9\end{array}$ & $\begin{array}{l}20 \\
25\end{array}$ & $\begin{array}{l}13 \\
31\end{array}$ \\
\hline biomedicinske & Medicinski & $\begin{array}{l}\mathrm{M} \\
\check{Z}\end{array}$ & $\begin{array}{r}5 \\
12\end{array}$ & $\begin{array}{l}10 \\
25\end{array}$ & $\begin{array}{r}9 \\
25\end{array}$ \\
\hline tehničke & $\begin{array}{l}\text { Građevinski i } \\
\text { Elektrotehnički }\end{array}$ & $\begin{array}{l}\mathrm{M} \\
\check{Z}\end{array}$ & $\begin{array}{l}72 \\
14\end{array}$ & $\begin{array}{r}42 \\
8\end{array}$ & $\begin{array}{l}37 \\
16\end{array}$ \\
\hline & Ukupno & $\begin{array}{l}\mathrm{M} \\
\check{Z}\end{array}$ & $\begin{array}{l}171 \\
179\end{array}$ & $\begin{array}{l}155 \\
195\end{array}$ & $\begin{array}{l}131 \\
230\end{array}$ \\
\hline
\end{tabular}

U istraživanju su od ostalih sociodemografskih varijabli

(1) TABLICA 3

Obrazovanie i zanimanje roditelja korišteni i stupanj obrazovanja oca i majke te zanimanje oca i majke. U Tablici 3 prikazani su stupanj obrazovanja i zanimanje roditelja.

\begin{tabular}{llrr}
\hline & & $r$ & Otac \\
& & $\begin{array}{r}\text { Majka } \\
(\%)\end{array}$ & $\begin{array}{r}(\%) \\
\text { Stupanj obrazovanja }\end{array}$ \\
& Nezavršena ili završena osnovna škola & 6,8 & 14,7 \\
& Srednja škola & 61,9 & 64,6 \\
& Viša škola ili fakultet & 31,3 & 20,7 \\
& Čelnici i dužnosnici državnih tijela, direktori & 9,8 & 5,0 \\
& Stručnjaci, znanstvenici, inženjeri & 17,0 & 18,2 \\
& Tehničari & 20,0 & 27,6 \\
& Službenici & 1,8 & 13,7 \\
& Uslužna i trgovačka zanimanja & 4,9 & 22,1 \\
& Poljoprivredni radnici & 7,4 & 2,1 \\
& Zanimanja u obrtu i pojedinačnoj proizvodnji & 24,4 & 5,9 \\
& Rukovatelji strojevima, vozilima, sastavljači proizvoda & 6,4 & 2,5 \\
& Jednostavna zanimanja & 6,6 & 2,9 \\
& Vojna zanimanja & 1,6 & 0,0 \\
\hline
\end{tabular}

Varijabla zanimanja roditelja mjerena je pitanjem otvorenoga tipa, nakon čega su dobiveni odgovori rekodirani, tj. kategorizirani prema rodovima zanimanja definiranim u Nacionalnoj klasifikaciji zanimanja iz 2010. godine. Kategorizirani odgovori prikazani su u Tablici 3,8 iz koje se vidi da je znača- 
DRUŠ. ISTRAŽ. ZAGREB GOD. 20 (2011),

BR. 4 (114),

STR. $943-965$

ŠUNDALIĆ, A., PAVIĆ, Ž.: IZMEĐU VRIJEDENOSTI...

(1) TABLICA 4

Skala prihvaćania koruptivnih načina društvenog uspieha jan dio studentske populacije višega socijalnog podrijetla, tj. roditelji su u 1., 2. i 3. kategoriji zanimanja (45,4\% očeva i $51 \%$ majki).

U istraživanju su uglavnom upotrijebljena pitanja kakva se obično rabe $u$ konstrukciji skala Likertova tipa, a u njima se od ispitanika tražio stupanj slaganja s ponuđenim tvrdnjama (od "uopće se ne slažem" do "potpuno se slažem"), i pitanja u kojima se od ispitanika tražio jedan odgovor ili više odgovora ("multiple choice"). U skladu s postavljenim hipotezama, ova su se pitanja odnosila na vrednovanje obrazovanja kao meritokratskoga mehanizma, prihvaćanje koruptivnih načina ponašanja i percepciju važnosti obrazovanja za postizanja važnih društvenih položaja. Pitanja koja su se odnosila na vrednovanje obrazovanja i prihvaćanje koruptivnih načina dolaženja do društvenog uspjeha faktorizirana su kako bi se vidjelo predstavljaju li isti konstrukt, tj. čine li jednodimenzionalnu skalu.

Prvim mjernim instrumentom nastojalo se izmjeriti u kojoj mjeri ispitanici prihvaćaju koruptione načine dolaska do društvenog uspjeha. Instrument su činile 4 čestice, a komponentna faktorska analiza, sa svojstvenom vrijednosti većom od 1 kao kriterijem ekstrakcije, pokazala je da čine jedan faktor.

Čestica

Korelacija $\mathrm{s}$ faktorom

1. Opravdano je ponekad dati mito ako će nam to pomoći u pronalaženju posla.

2. U redu je iskoristiti rodbinske veze prilikom pronalaženja posla u državnoj službi ili državnim poduzećima.

3. Za uspjeh u poslu ponekad je opravdano raditi manje nezakonitosti.

4. Posve je u redu ako neki roditelji svojoj djeci mogu omogućiti lakši put do uspjeha u životu.

Napomena: Ekstrahirani faktor tumači 53,1\% varijance.

Drugi mjerni instrument činile su čestice kojima se po-

(U) TABLICA 5

Skala vrednovanja obrazovanja kao meritokratskoga mehanizma kušalo izmjeriti koliko ispitanici vjeruju u vrijednost obrazovanja kao meritokratskoga mehanizma. I ovaj su instrument činile četiri čestice, a faktorska analiza pod komponentnim modelom pokazala je da čine jedan faktor.

\begin{tabular}{cc} 
Čestica & $\begin{array}{c}\text { Korelacija } \\
\text { s faktorom }\end{array}$ \\
\hline
\end{tabular}

1. Visokoobrazovani stručnjaci jedini zaslužuju rukovodeća mjesta na svojem području.

2. Visokoobrazovani stručnjaci na rukovodećim i odgovornim položajima zaslužuju visoka primanja.

3. Visokoobrazovani stručnjaci na rukovodećim i odgovornim položajima zaslužuju društveni ugled i priznanje.

4. Obrazovaniji pojedinac uvijek zaslužuje veću plaću od manje obrazovanoga. 
Oba mjerna instrumenta, unatoč malom broju čestica, imaju relativno solidan stupanj pouzdanosti (mjeren Cronbachovim $\alpha$-koeficijentom), ${ }^{9}$ a zbroj rezultata kod odgovora na pojedinačne čestice činio je kompozitnu varijablu, koja je upotrijebljena u kasnijoj analizi.

\section{REZULTATI ISTRAŽIVANJA I RASPRAVA}

Prvom hipotezom predvidjeli smo da će obrazovanje, unatoč nepovoljnom sociokulturnom nasljeđu, biti visoko vrednova-

(1) TABLICA 6

Prihvaćenost

obrazovanja kao

meritokratskoga

mehanizma

no kao mehanizam meritokratske selekcije i nagrađivanja. Ova hipoteza provjeravana je kroz odgovore na četiri pitanja, koja, kako je napomenuto, čine jednodimenzionalnu skalu. Stupanj slaganja s ovim tvrdnjama naveden je u Tablici 6.

\begin{tabular}{lrrrcr} 
& $\begin{array}{r}\text { Uopće } \\
\text { se ne }\end{array}$ & Ne & $\begin{array}{r}\text { Podjednako } \\
\text { se slažem }\end{array}$ & Potpuno \\
Tlažem & slažem se & i ne slažem & Slažem se & se slažem \\
\hline
\end{tabular}

1. Visokoobrazovani stručnjaci jedini

zaslužuju rukovodeća mjesta

na svojem području.

1,9

8,9

22,6

39,4

27,2

2. Visokoobrazovani stručnjaci na rukovodećim i odgovornim položajima zaslužuju visoka primanja. 0,6

3. Visokoobrazovani stručnjaci na rukovodećim i odgovornim položajima zaslužuju društveni ugled i priznanje.
1,4

4,6

1,9

19,8
16,9

54,4

25,4

Obrazovaniji pojedinac uvijek zaslužuje veću plaću od manje obrazovanoga.

Iz tablice se vidi da su ove tvrdnje relativno visoko prihvaćene. Tako se s tvrdnjom da "visokoobrazovani stručnjaci jedini zaslužuju rukovodeća mjesta na svojem području" slaže ili potpuno slaže $67,1 \%$ ispitanika, dok se daljnjih 22,3\% podjednako slaže i ne slaže. Najmanji je stupanj slaganja s tvrdnjom po kojoj "obrazovaniji pojedinac uvijek zaslužuje veću plaću od manje obrazovanoga", no i s tom tvrdnjom ne slaže se ili se uopće ne slaže samo $22,1 \%$ sudionika istraživanja.

S obzirom na to da ove čestice čine jedinstven konstrukt, izračunana je i raspodjela sumarnih rezultata na njima. Ova raspodjela, prikazana u Grafikonu 1, upućuje na sličan zaključak kao i frekvencije prikazane u Tablici 6 - obrazovanje je relativno široko prihvaćeno među istraživanom populacijom kao meritokratski mehanizam. Naime, minimalni sumarni rezultat iznosio je 4, a maksimalni 20 , a vidi se da velika većina ispitanika postiže rezultat veći od 12 (srednji stupanj slaganja). 
DRUŠ. ISTRAŽ. ZAGREB GOD. 20 (2011),

BR. 4 (114)

STR. 943-965

ŠUNDALIĆ, A., PAVIĆ, Ž.: IZMEĐU VRIJEDNOSTI...

$\rightarrow$ GRAFIKON 1 Raspodjela rezultata na skali prihvaćenosti obrazovanja kao meritokratskoga mehanizma

(4) TABLICA 7

Cimbenici dolaska do važnoga položaja u poduzeću

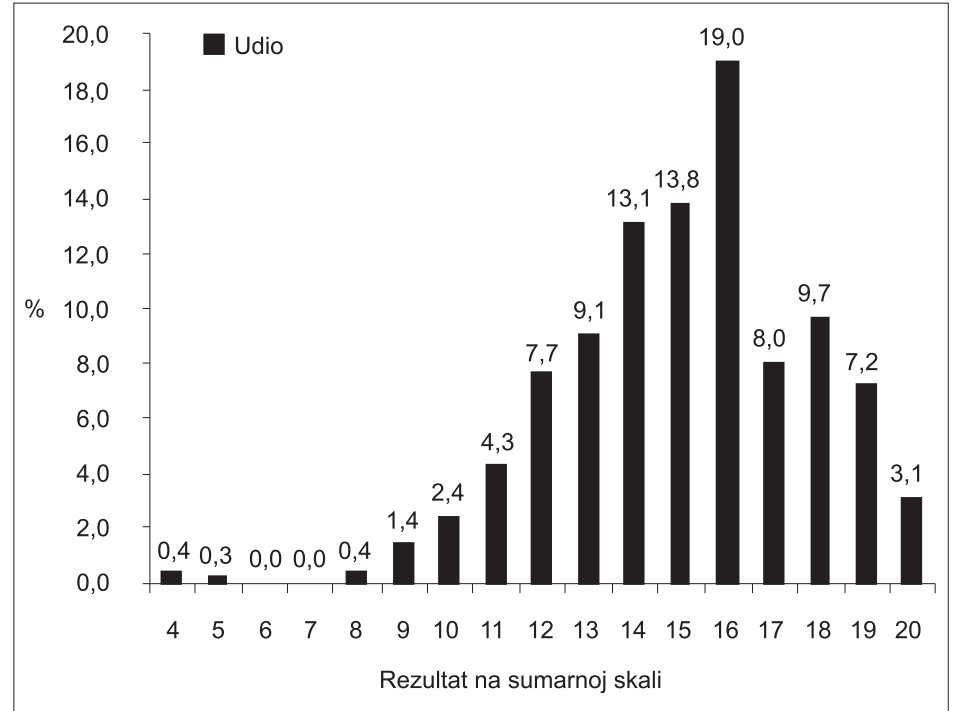

Analiza frekvencija odgovora na pojedine tvrdnje, kao i raspodjela rezultata na sumarnoj skali, upućuju na to da je obrazovanje široko prihvaćeno kao meritokratski mehanizam, tj. da je hipoteza 1 potvrđena.

Drugom se hipotezom predvidjelo da u hrvatskom društvu još prevladava mišljenje kako za dolaženje na određene socijalne položaje (funkcije na čelu poduzeća, općine, grada, a posebice funkcije obnašanja političke vlasti) obrazovanje nije ključni faktor. Ispitanike se $u$ istraživanju pitalo da procijene koji je najvažniji čimbenik dolaska do važnoga položaja u poduzeću, tj. koji su čimbenici danas presudni za profesionalni uspjeh. Iz Tablice 7 vidi se da se kao najvažniji čimbenici procjenjuju rodbinske i prijateljske veze te članstvo $u$ političkoj stranci.
Najvažniji čimbenik za postizanje utjecajnoga, moćnog položaja u poduzeću

$\mathrm{f}$

$\%$

Članstvo u političkoj stranci

Rodbinske i prijateljske veze

Socijalno podrijetlo (ugled obitelji, podrijetlo iz nekoga kraja i sl.)

Osobna snalažljivost

Diploma (završena potrebna razina obrazovanja)

Diploma i provjereno znanje te sposobnost za određeno radno mjesto

Ukupno

$\begin{array}{rr}109 & 32,4 \\ 181 & 53,7 \\ 2 & 0,6 \\ 11 & 3,3 \\ 4 & 1,2 \\ 29 & 8,6 \\ 336 & 100\end{array}$

I u sljedećom se bloku pitanja pokušalo utvrditi u kojoj se mjeri ispitanici slažu s tvrdnjama koje se odnose na to u kojoj je mjeri obrazovanje prisutno kao mehanizam dodjeljivanja važnih društvenih položaja u hrvatskom društvu. I ovdje se može vidjeti (Tablica 8) da sudionici istraživanja uglavnom smatraju kako se dodjeljivanje važnih društvenih položaja ne od- 
DRUŠ. ISTRAŽ. ZAGREB GOD. 20 (2011), BR. $4(114)$

STR. 943-965

ŠUNDALIĆ, A., PAVIĆ, Ž.: IZMEĐU VRIJEDNOSTI..

(1) TABLICA 8

Tvrdnje o realnoj važnosti obrazovanja u Hrvatskoi vija posjedovanjem obrazovnih kvalifikacija. Tako se, primjerice, čak 79,1\% ispitanika slaže ili potpuno slaže s tvrdnjom da je "za karijeru važnije imati utjecajnog prijatelja ili rođaka ("vezu") nego fakultetsku diplomu", a 79,5\% da "u hrvatskom društvu još uvijek vrijedi pravilo 'snađi se, druže"'. Stupanj slaganja s tvrdnjom po kojoj većina građana u školovanju ne vidi put u svoju karijeru nešto je manji, no i tu je broj ispitanika koji se slažu s tvrdnjom veći od broja onih koji se s njom ne slažu (34,4\% prema $20,4 \%)$, a slično je i s tvrdnjama o tome da školovane osobe bez političke podrške ne mogu doći do važnijega položaja (42,7\% prema $19,1 \%)$ i da opća društvena klima pozitivno utječe na važnost obrazovanja i diplome za uspjeh u karijeri (23,0\% onih koji se slažu i 38,1\% onih koji se ne slažu). Doduše, veći broj ispitanika izrazio je slaganje nego neslaganje s tvrdnjom po kojoj sve više prevladava shvaćanje da je obrazovanje jedini put osobnog uspjeha, no tu je više riječ o procjeni tendencije, a manje o sadašnjem stanju stvari.

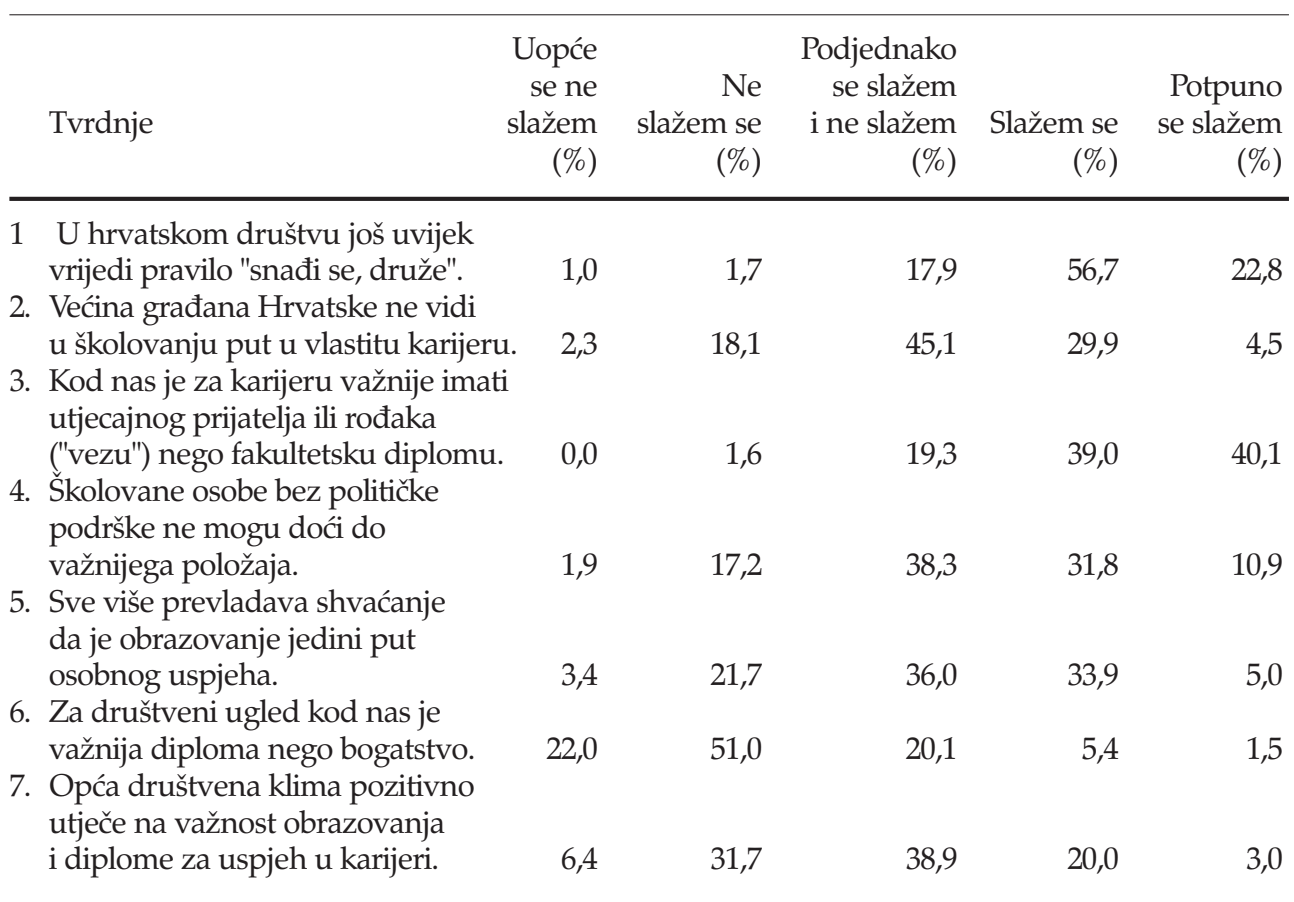

Odgovori na ovu seriju pitanja upućuju na to da ispitanici smatraju kako obrazovanje u Hrvatskoj još uvijek nije dominantan put do društvenog uspjeha. Ove tvrdnje, kao i distribucija odgovora na prethodno pitanje (Tablica 7), pokazuju da je hipoteza 2, postavljena u ovome istraživanju, potvrđena.

Kako je napomenuto, $\mathrm{u}$ istraživanju se, osim skale vrednovanja obrazovanja, primjenjivala i skala prihvaćenosti koruptivnih načina postizanja društvenog uspjeha. Rezultat na 
DRUŠ. ISTRAŽ. ZAGREB GOD. 20 (2011)

BR. 4 (114)

STR. $943-965$

ŠUNDALIĆ, A., PAVIĆ, Ž.: IZMEĐU VRIJEDNOSTI...

\section{? GRAFIKON 2}

Prihvaćanje koruptivnih načina postizanja uspjeha

(1) TABLICA 9 Odnos vrednovanja obrazovanja i koruptivnih načina postizanja uspieha sumarnoj skali prikazan je u grafikonu i pokazuje da je prihvaćenost ovih oblika ponašanja relativno niska (najmanji rezultat je 4 , a najveći 20 , dok se većina ispitanika nalazi u donjem dijelu skale).

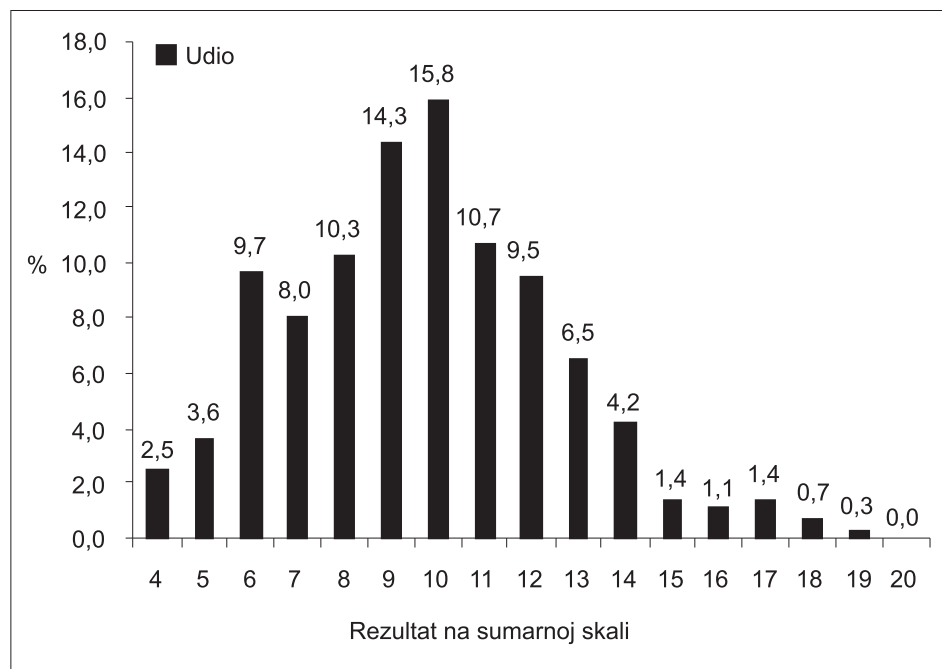

Kako bi se vidjelo u kojoj mjeri kod ispitanika postoji eventualna disonanca između vrednovanja koruptivnih načina dolaženja do društvenog uspjeha i vrijednosti obrazovanja (objašnjeno $u$ teorijsko-hipotetskom dijelu), ispitanici su prema rezultatima na ovim skalama podijeljeni u dvije skupine oni s rezultatom manjim od sredine skale i oni s rezultatom većim od sredine skale. Ukrštanjem ovako dobivenih varijabli dobiveni su rezultati prikazani u Tablici 9.

\begin{tabular}{llll}
\hline & $\begin{array}{l}\text { Niži rezultat } \\
\text { na skali prihvaćanja } \\
\text { vrijednosti obrazovanja }\end{array}$ & $\begin{array}{l}\text { Viši rezultat } \\
\text { na skali prihvaćanja } \\
\text { vrijednosti obrazovanja }\end{array}$ & Ukupno \\
\hline Niži rezultat na skali & 45 & 255 & 300 \\
prihvaćanja korupcije & $15,0 \%$ & $85,0 \%$ & $100,0 \%$ \\
Viši rezultat na skali & 15 & 41 & 56 \\
prihvaćanja korupcije & $26,8 \%$ & $73,2 \%$ & $100,0 \%$ \\
Ukupno & 60 & 296 & 356 \\
& $16,9 \%$ & $83,1 \%$ & $100,0 \%$ \\
\hline
\end{tabular}

$\chi^{2}=4,68 ; p=0,03 ;$ Cramerov V=0,11;C=0,11

Iz tablice se vidi da se može odbaciti statistička nulta hipoteza o nepovezanosti dviju varijabli. Analiziranjem frekvencija iz tablice vidi se da su pojedinci koji imaju viši rezultat na skali prihvaćanja korupcije nešto manje skloni prihvaćanju vrijednosti obrazovanja. Oko $73,2 \%$ ispitanika koji imaju viši 
DRUŠ. ISTRAŽ. ZAGREB GOD. 20 (2011), BR. $4(114)$

STR. $943-965$

ŠUNDALIĆ, A., PAVIĆ, Ž.: IZMEEU VRIJEDNOSTI... rezultat na skali prihvaćanja korupcije ipak prihvaća vrijednost obrazovanja, u usporedbi sa $85,0 \%$ ispitanika koji imaju niži rezultat na skali prihvaćanja koruptivnih načina društvenog uspjeha. Ova mala razlika odražava se i u mjerama asocijacije, koje su vrlo niske. Stoga se i može reći da se prihvaćanje korupcije kao načina postizanja uspjeha u pravilu odvija istodobno s prihvaćanjem vrijednosti obrazovanja, tj. da kod većega broja ispitanika koji prihvaćaju korupciju postoji vrijednosna disonanca, čime je hipoteza o koruptivnim vrijednostima kao adaptaciji na društvenu realnost prihvaćena.

Uzevši u obzir sve ispitanike, vidi se da kod većine njih (71,6\%, tj. njih 255 od 356) postoji sukladnost između ovih dviju vrijednosti, tj. da vrijednosna disonanca kod njih nije prisutna (konzistentni meritokratski svjetonazor). Naime, ovi ispitanici prihvaćaju vrijednost obrazovanja kao meritokratskoga mehanizma, a istodobno odbijaju koruptivne načine postizanja društvenog uspjeha. Kod 11,5\% ispitanika (41 njih) može se govoriti o adaptaciji na društvenu realnost, tj. o prihvaćanju načelne vrijednosti obrazovanja, uz istodobno prihvaćanje korupcije. Kod 12,6\% ispitanika (45 njih) zapaža se odbacivanje nelegitimnih načina postizanja uspjeha, ali i neprihvaćanje obrazovanja (sociokulturno naslijeđeni antiintelektualizam ili slabo povjerenje $\mathrm{u}$ hrvatski obrazovni sustav), dok samo 4,2\% ispitanika (ili 15 njih) prihvaća korupciju, ali i odbacuje obrazovanje (pretpostavljeno sociokulturno naslijeđe antiintelektualizma, nepotizma i korupcije). Iz ovih se rezultata vidi da je konzistentni meritokratski svjetonazor najprisutniji $\mathrm{u}$ istraživanoj populaciji, tj. da vrijednosna disonanca između dviju ispitivanih vrijednosti, utvrđena kod onih ispitanika koji prihvaćaju koruptivne načine postizanja uspjeha, nije značajnije prisutna kada se $u$ obzir uzmu svi ispitanici.

Sažeto govoreći, rezultati istraživanja upućuju na visoko vrednovanje obrazovanja kao mehanizma dodjeljivanja društvenih nagrada i položaja, kao i na odbijanje koruptivnih načina njihovoga postizanja. S druge strane, društvena se stvarnost percipira kao izrazito nemeritokratska. Ovaj se svojevrsni paradoks može objasniti na tri načina.

Kao prvo, moguće je da rezultati odražavaju specifičnost studenata viših godina studija kao sudionika ovoga istraživanja. Riječ je o mladim ljudima koji su već upisivanjem fakulteta i dolaskom do viših godina studija pokazali svoju opredijeljenost za postizanje društvenoga položaja obrazovanjem (formalnim kvalifikacijama). K tome, riječ je o populaciji koja još nije ozbiljnije zakoračila u svijet rada i "stvarni život", pa se još uvijek (?!) nije adaptirala na koruptivnu društvenu realnost. 
DRUŠ. ISTRAŽ. ZAGREB GOD. 20 (2011),

BR. $4(114)$

STR. 943-965

ŠUNDALIĆ, A., PAVIĆ, Ž. IZMEĐU VRIJEDENOSTI...

\section{ZAKLJUČAK}

Prema drugom mogućem objašnjenju, percepcija društvene realnosti i stvarno postupanje mogu se donekle razilaziti. Učestalost koruptivnoga ponašanja može se procjenjivati na osnovi heuristike dostupnosti, tj. medijskih izvještaja o visokoprofiliranim slučajevima korupcije i javnoga diskursa o njoj. Na ovakav zaključak donekle upućuju i rezultati drugih istraživanja. Tako su podaci za Hrvatsku iz Europske studije vrednota (European Values Study), kada je riječ o mitu, korupciji, utaji i izbjegavanju poreza, dobrim dijelom slični rezultatima ovdje prikazanog istraživanja. ${ }^{10}$ Tako primanje mita na radnom mjestu nikada ne opravdava 78,3\% (1999.), tj. 73,8\% ispitanika (2008.). Međutim, istodobno 43,8\% ispitanika (1999.), tj. 44,6\% ispitanika (2008.), smatra da su svi ili mnogi drugi građani spremni podmićivati za usluge kako bi izbjegli porez. Isto tako, 36,4\% ispitanika (1999.), tj. 40,9\% ispitanika (2008.), smatra da su svi ili mnogi građani spremni uzimati mito za posao koji i inače trebaju obaviti kao zaposlenici. Utaju i izbjegavanje poreza nikada ne opravdava 60,8\% (1999.), tj. 57\% ispitanika (2008.), ali se istodobno smatra da bi drugi, gotovo svi i mnogi, to bili spremni učiniti: 52,3\% (1999.), 47,1\% (2008.). U svim se ovim primjerima, dakle, vidi da je opravdavanje raznih oblika koruptivnoga ponašanja, a time i neizravna vlastita spremnost na koruptivno ponašanje, manje od procjene učestalosti tih oblika ponašanja kod drugih ljudi.

Naposljetku, moguće je da ovakva anketna istraživanja, unatoč anonimnosti odgovora, odražavaju socijalno poželjne, a ne iskrene odgovore. Zbog toga bi učestalost meritokratske orijentacije kod ispitanika mogla biti precijenjena.

Prema mjerama percepcije korupcije, Hrvatska ulazi u visokokorumpirane zemlje. Društveni razvitak Hrvatske u prošlosti je bio obilježen procesima koji su nepovoljno utjecali na razvoj meritokratskih normi ponašanja i na oslanjanje na obrazovanje kao na mehanizam dodjeljivanja društvenih položaja i nagrada. U ovome se radu nastojalo utvrditi, doduše na temelju istraživanja rađenog na prigodnom uzroku specifične - studentske - populacije, u kojoj se mjeri može govoriti o utjecaju sociokulturnoga nasljeđa koje obrazovanju odriče njegovu meritokratsku funkciju i značenje, odnosno u kojoj se mjeri koruptivno ponašanje može objasniti adaptacijom na društvenu realnost obilježenu korupcijom. Ova se ideja operacionalizirala kroz (ne)postojanje vrijednosne disonance između vrednovanja obrazovanja kao meritokratskoga mehanizma i vrednovanja koruptivnih načina dolaženja do društvenog uspjeha. Rezultati istraživanja na studentskoj populaciji Osječkoga sveučilišta upućuju na visoko vrednovanje 
DRUŠ. ISTRAŽ. ZAGREB GOD. 20 (2011), BR. $4(114)$ STR. $943-965$

ŠUNDALIĆ, A., PAVIĆ, Ž.: IZMEĐU VRIJEDNOSTI... obrazovanja kao mehanizma društvene selekcije, kao i na visok stupanj odbijanja koruptivnih načina postizanja društvenog uspjeha, što znači da istraživana populacija pokazuje konzistentan meritokratski svjetonazor. Rezultati su pokazali da čak i kod većine onih pojedinaca koji prihvaćaju koruptivne načine postizanja uspjeha postoji visoko vrednovanje obrazovanja, što označuje postojanje vrijednosne disonance, koja bi mogla biti posljedica adaptacije na realnost $\mathrm{u}$ kojoj se načini postizanja društvenog uspjeha često, prema uobičajenoj percepciji utvrđenoj i u ovom istraživanju, kriju u nedopuštenim sredstvima. Ovakav se zaključak temelji na teorijskoj pretpostavci da negativno vrednovanje obrazovanja i pozitivno vrednovanje koruptivnih načina dolaženja do društvenog uspjeha čine jedinstven vrijednosni sklop naslijeđen iz hrvatske prošlosti, odnosno da bi kod konzistentnoga meritokratskog svjetonazora ove dvije vrijednosti trebale biti usko povezane. Alternativna pretpostavka o relativnoj neovisnosti ovih dviju vrijednosti, pri čemu jedna od njih može, a druga ne mora biti prenesena kao dio sociokulturnoga nasljeđa, ponudila bi i drugačije zaključke o odnosu sociokulturnoga nasljeđa i adaptacije na realnost kao dvama mogućim objašnjenjima koruptivnoga ponašanja.

\section{BILJEŠKE}

${ }^{1}$ Korupcije nije bio oslobođen ni kapitalistički Zapad. E. Banfield je prikazuje kao "amoralni familizam" u sličnim razmjerima. Glavno pravilo u skladu s kojim se djeluje u društvu amoralnoga familizma jest maksimalno uvećati materijalne vrijednosti, kratkoročno iskoristiti probitke uže obitelji, pretpostavljajući da će i ostali učiniti isto. Primjer iz političkoga života: "U društvu amoralnih familista stranački radnici prodat će svoje usluge najboljem ponuđaču. Njihova sklonost promjeni strane pridonijet će naglim pomacima u snazi stranaka na biralištima. Ako lokalne vođe na vrijeme ne naplate potraživanja od središnjica, postoji velika opasnost za njihovo konvertitstvo. (...)" (Bežovan, 2005., 43-49).

2 Teret kulture seljačkoga društva iz prve Jugoslavije nije mogao nestati brzo. Predmoderno stanje u hrvatskom društvu tridesetih godina dvadesetog stoljeća pokazuju podaci po kojima više od $70 \%$ stanovništva živi od poljoprivrede. U Hrvatskoj i Slavoniji bilo je 1931. oko 404000 poljoprivrednih gospodarstava. Od toga čak ih je 36\% imalo posjed manji od 2 ha, a samo $5,7 \%$ posjeda bilo je veće od 10 ha (Mirković, 1950., 31). Usporedbe radi, treba navesti podatke koji se odnose na 1830. u Europi: Engleska je tada imala 33\% zaposlenih u poljoprivredi, Njemačka 30,5\%, Francuska 38\% (Mirković, 1937., 67).

3 Oba rada temelje se na empirijskim istraživanjima rađenim na slučajnim uzorcima stanovništva Hrvatske tijekom osamdesetih godina 20. stoljeća.

4 Iako Lazić pokazuje da s vremenom jača tendencija zatvaranja i smanjenja međugeneracijske pokretljivosti, u čemu i školski sustav 
DRUŠ. ISTRAŽ. ZAGREB GOD. 20 (2011), BR. 4 (114),

STR. $943-965$

ŠUNDALIĆ, A., PAVIĆ, Ž. IZMEĐU VRIJEEDNOSTI... ima važnu ulogu. Tako se prema podacima iz ovoga istraživanja, $u$ srednjim školama, koje su školovale za tipična radnička zanimanja, nalazilo oko $3 \%$ djece direktora, $6 \%$ djece političkih rukovoditelja te oko $30 \%$ djece NKV i KV radnika. Istodobno je u sveučilišno obrazovanje bilo uključeno oko $57 \%$ djece direktora, oko $53 \%$ djece političkih rukovoditelja te samo svako dvanaesto dijete NKV radnika. (Lazić, 1987., 142). U Sekulićevu radu ovo zatvaranje nije jednoznačno, jer generacijska analiza utvrđuje da srednja generacija pokazuje više međugeneracijske pokretljivosti od starije i mlađe, iako su razlike po pojedinim društvenim slojevima relativno velike (Sekulić, 1991., 135-165).

5 Hrvatska se tako na temelju Indeksa percepcije korupcije u 2010. nalazila na 62. mjestu od ukupno 178 zemalja u kojima se ovaj indeks mjeri (Transparency International Croatia, 2011.). Na raširenost koruptivnoga ponašanja među javnim dužnosnicima i građanima upućuju i podaci iz drugih istraživanja (npr. Rimac, 2010. i Štulhofer, 2004.).

6 Županov to vidi kao sukob političkog i poduzetničkog modela kapitalizma, tzv. modelski dualizam (Županov, 1995.).

7 Podaci dobiveni od Sveučilišta J. J. Strossmayera u Osijeku.

${ }^{8}$ Neki od naziva rodova zanimanja $\mathrm{u}$ tablici navedeni su u skraćenom obliku.

${ }^{9}$ U slučaju prve skale Cronbachov alfa iznosi 0,71, a u slučaju druge 0,72.

10 Ovdje su upotrijebljene frekvencije odgovora objavljene $u$ Rimac (2010.).

\section{LITERATURA}

Akers, R. L. (2009.), Social Learning and Social Structure: A General Theory of Crime and Deviance, New Brunswick, Transaction Publishers.

Bežovan, G. (2005.), Civilno društvo, Zagreb, Nakladni zavod Globus. Bićanić, R. (2004.), Ekonomska podloga hrvatskog pitanja, Zagreb, Dom i svijet - Ekonomski fakultet Sveučilišta u Zagrebu.

Čaldarović, O., Štulhofer, A., Kufrin, K., Glavašević, B., Odak, I., Gregurović, M. i Detelić, M. (2009.), Combating Corruption in Croatia: From Expert Perceptions to Policy-Oriented Action Strategies and Back. Revija za sociologiju, 40[39] (1-2): 3-22.

Friedman, M. (1992.), Kapitalizam i sloboda, Zagreb, Globus - Školska knjiga.

Goldthorpe, J. (1997.), Problems of 'Meritocracy'. U: A. H. Halsey, H. Lauder, P. Brown i A. S. Wells (ur.), Education: Culture, Economy, and Society (str. 663-682), Oxford, Oxford University Press.

Kregar, J. (1999.), Nastanak predatorskog kapitalizma i korupcija, Zagreb, RIFIN.

Krištofić, B. (1997.), Manageri i modernitet. U: B. Golub, B. Krištofić i D. Čengić (ur.), Znanstvene i privredne elite (str. 41-65), Zagreb, Institut za društvena istraživanja.

Lazić, M. (1987.), U susret zatvorenom društvu? Klasna reprodukcija u socijalizmu, Zagreb, Naprijed. 
DRUŠ. ISTRAŽ. ZAGREB GOD. 20 (2011), BR. 4 (114) STR. 943-965

ŠUNDALIĆ, A., PAVIĆ, Ž.: IZMEĐU VRIJEDNOSTI..
Lazić, M. i Cvejić, S. (2007.), Class and Values in Postsocialist Transformation in Serbia. International Journal of Sociology, 37 (3): 54-74.

Lipset, S. M. i Lenz, G. S. (1999.), Corruption, Culture and Markets. Rukopis, George Mason University, Arlington, 24 str.

Mirković, M. (1950.), Ekonomika agrara FNRJ, Zagreb, Nakladni zavod Hrvatske.

Mirković, M. (1937.), Održanje seljačkog posjeda, Zagreb, Hrvatska naklada. Morin, E. (2008.), Etika, Zagreb, Masmedia.

Pusić, V. (1992.), Vladaoci i upravljači, Zagreb, Novi Liber.

Rimac, I. (2010.), Komparativni pregled odgovora na pitanja u anketi Europske studije vrednota 1999. i 2008. Bogoslovska smotra, 80 (2): 425-525.

Sandholtz, W. i Taagepera, R. (2005.), Corruption, Culture and Communism. International Review of Sociology, 15 (1): 109-131. doi:10. 1080/03906700500038678

Sekulić, D. (1991.), Strukture na izmaku: klase, sukobi i socijalna mobilnost, Zagreb, Sociološko društvo Hrvatske.

Štulhofer, A. (1999.), Proces privatizacije u Hrvatskoj i hrvatska javnost 1996-1998: povratak u budućnost? U: D. Čengić i I. Rogić (ur.), Privatizacija i javnost (str. 87-114), Zagreb, Institut društvenih znanosti Ivo Pilar. Štulhofer, A. (2004.), Percepcija korupcije i erozija društvenog kapitala u Hrvatskoj 1995.-2003. Politička misao, 41 (3): 156-169.

Šundalić, A. (2004.), Hrvatsko društvo i integracijski procesi, Osijek, Matica hrvatska.

Tavits, M. (2010.), Why Do People Engage in Corruption? The Case of Estonia. Social Forces, 88 (3): 1257-1279. doi:10.1353/sof.0.0288

Transparency International Croatia (2011.), Indeks percepcije korupcije 2010, http://www.transparency.hr/index.php?kategorija $=17$ (27. 5. 2011.). Županov, J. (1985.), Samoupravljanje i društvena moć, Zagreb, Globus. Županov, J. (1995.), Poslije potopa, Zagreb, Nakladni zavod Globus.

Županov, J. (2001.), Industrijalizirajuća i dezindustrijalizirajuća elita u Hrvatskoj u drugoj polovici 20. stoljeća. U: D. Čengić i I. Rogić (ur.), Upravljačke elite i modernizacija (str. 11-36), Zagreb, Institut društvenih znanosti Ivo Pilar.

\section{Between the Value of Education and Negative Socio-Cultural Legacy}

Antun ŠUNDALIĆ, Želiko PAVIĆ

Faculty of Economics, Osijek

In spite of the complexity of the concept of meritocracy, in meritocratic societies social standings and social rewards should be closely connected to the level of individuals' education. In Croatian society non-meritocratic, corruptive behaviour is widespread, while explanations of its causes range from non-favourable socio-cultural legacy (traditional 
DRUŠ. ISTRAŽ. ZAGREB GOD. 20 (2011)

BR. $4(114)$

STR. $943-965$

ŠUNDALIĆ, A., PAVIĆ, Ž.: IZMEĐU VRIJÉDNOSTI... peasant culture, socialism) to rational adaptation to social reality. In this paper, based on the research of the acceptance of the value of education as a mechanism of social selection and rewards, as well as the acceptance of corruptive behaviour, an attempt has been made to assess whether it is still justifiable to speak of a negative impact of socio-cultural legacy. The research, carried out on a convenient sample of students of J. J. Strossmayer University in Osijek, at the beginning of 2011, has shown that respondents believe that processes which allocate social standings are essentially non-meritocratic. However, at the same time most of the respondents hold meritocratic values, while only a smaller part of them have adapted themselves to social reality by simultaneously accepting value of education and expressing readiness to engage in corruptive behaviour. Bearing in mind that the majority of respondents who express readiness to engage in corrupt behaviour show value dissonance, the authors conclude that rational adaptation can be the cause of this readiness.

Keywords: education, meritocracy, value dissonance, social values, corruption

\section{Zwischen Vorzügen der Bildung und negativem soziokulturellem Erbe}

Antun ŠUNDALIĆ, Željko PAVIĆ

Wirtschaftswissenschaftliche Fakultät, Osijek

Trotz aller Komplexität des Begriffs der Meritokratie müssten in meritokratischen Gesellschaften die gesellschaftliche Position und gesellschaftliche Auszeichnungen in engem Zusammenhang mit dem Bildungsgrad einer jeweiligen Person stehen. In der kroatischen Gesellschaft ist nichtmeritokratisches und korruptes Verhalten sehr ausgeprägt; die Erklärungen hierfür reichen von Verweisen auf ein nachteiliges soziokulturelles Erbe (traditionelle Bavernkultur, Sozialismus) bis hin zur Sichtweise, dass es sich hierbei um eine rationale Anpassung an die gesellschaftliche Realität handle. Der vorliegende Artikel entstand in Anlehnung an Untersuchungen zur Anerkennung des Werts von Bildung, aufgefasst als Mechanismus gesellschaftlicher Selektion und Belohnung, wobei überdies der Frage nachgegangen wird, inwiefern korrupte Vorgehensweisen zur Sicherung von gesellschafflichem Erfolg akzeptiert werden. Die Verfasser versuchten zu ermitteln, inwiefern immer noch von einer negativen Auswirkung des soziokulturellen Erbes die Rede sein könne, und führten zu Beginn des Jahres 2011 eine entsprechende Untersuchung an der Universität "Josip Jurai Strossmayer" in Osijek durch. Die befragten Studenten vertraten die Meinung, dass führende gesellschaftliche 
DRUŠ. ISTRAŽ. ZAGREB GOD. 20 (2011), BR. 4 (114),

STR. $943-965$

ŠUNDALIĆ, A., PAVIĆ, Ž.: IZMEĐU VRIJEDNOSTI..
Positionen auf nicht-meritokratische Weise eingenommen würden. Gleichzeitig jedoch stellten die Forscher fest, dass die Studenten selbst überwiegend einem nichtmeritokratischen Weltbild anhingen, während ein geringer Teil der Umfrageteilnehmer insofern an die gesellschaftliche Wirklichkeit angepasst war, indem der Wert von Bildung zwar anerkannt, gleichzeitig aber auch korruptes Verhalten akzeptiert wurde. Im Blick auf die Tatsache, dass bei den meisten Umfrageteilnehmern, die korruptes Verhalten akzeptieren, eine Wertedissonanz zu verzeichnen ist, kommen die Verfasser zum Schluss, dass im Hintergrund einer solchen Haltung wahrscheinlich eine rationale Anpassung an die Wirklichkeit stehe.

Schlüsselbegriffe: Bildung, Meritokratie, Wertedissonanz, gesellschaftliche Werte, Korruption 